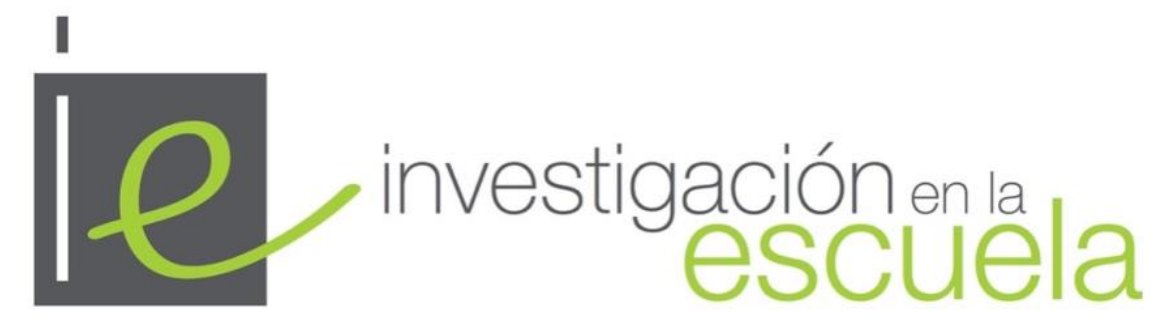

Revista de Investigación e Innovación Educativa nº 105, 2021 | e-ISSN 2443-9991

\title{
Comunidades Escolares de Aprendizaje Gulbenkian XXI: una experiencia innovadora
}

\author{
Gulbenkian XXI School Learning Communities: a case study of an innovative experience
}

iD Dra. Ana María Cristóvão, es investigadora en Centro de Investigação em Educação e Psicologia da Universidade de Évora (Portugal)·alc@uevora.pt·Orcid https://orcid.org/0000-0002-2276-9254

iD Dr. José Lopes Verdasca, es miembro integrado del Centro de Investigação em Educação e Psicologia da Universidade de Évora (Portugal)·jcv@uevora.pt·Orcid https://orcid.org/0000-0002-4099-421X

Cómo citar este artículo

Cristóvão, A.M. y Lopes Verdasca, J. (2021). Comunidades Escolares de Aprendizaje Gulbenkian XXI: una experiencia innovadora. Investigación en la Escuela, 105, 52-65. doi: https://doi.org/10.12795/IE.2021.i105.05

Resumen. El proyecto de investigación "Promoción del cambio en el aprendizaje: comunidades de aprendizaje escolar Gulbenkian XXI" buscó mejorar el aprendizaje de los estudiantes a través de la adquisición de conocimientos básicos dentro del plan de estudios formal y el desarrollo de habilidades de razonamiento analítico y práctico, resiliencia y responsabilidad y habilidades, emocionales, sociales y creativo. El proyecto se basó en el paradigma "Aprender para el Bienestar", este enfoque favorece un cambio de paradigmas, pasando de currículos diseñados fundamentalmente para el desarrollo cognitivo, a enfoques que apoyan el desarrollo de niños y jóvenes con las habilidades que necesitan para la vida. El proyecto tuvo una duración de cuatro cursos académicos y estuvo dirigido al 1 er ciclo y $2^{\circ}$ ciclo de la educación básica, específicamente al $3^{\circ}, 4^{\circ}, 5^{\circ}$ y $6^{\circ}$ años de escolaridad, comenzando con cohortes de alumnos de $3^{\circ}$ año de escolaridad. En él participaron siete clases de tres grupos de escuelas públicas de la región de Alentejo. Este artículo buscó analizar el impacto del proyecto a través del análisis de la eficiencia y efectividad educativa, comparando los resultados escolares y el tiempo de finalización del ciclo de los estudiantes del proyecto con estudiantes de la región de Alentejo y estudiantes de Portugal Continental. Los resultados indican que los estudiantes que participan en el proyecto registran puntuaciones más altas.

\begin{abstract}
The research project "Promoting Change in Learning: Gulbenkian XXI School Learning Communities" searches the improvement of student learning through the acquisition of basic knowledge within the formal curriculum and the development of analytical and practical reasoning skills, resilience and responsibility, emotional, social, and creative skills. The project is based on the "Learning for Well-being" paradigm, this approach favours a paradigm shift, moving from curricula designed fundamentally for cognitive development, to approaches that support the development of children and young people with the skills they need for life. The project is implemented in three schools from the Alentejo region, in the third, fourth grades (primary school), fifth and sixth grades (middle school), and staters with cohorts of third grade students. Seven classes from three groups of public schools in the Alentejo region participated in it. This article seeks to analyse the impact of the project through the analysis of educational efficiency and effectiveness, comparing the school results and the completion time of the students involved in the project with students from the Alentejo region and from Continental Portugal. The results indicate that the students who participate in the project register higher scores in the analysis of the different indicators.
\end{abstract}

\section{Palabras clave $\cdot$ Keywords}

Innovación educativa, aprendizaje para el bienestar, comunidad de aprendizaje, proyecto de investigación, aprendizaje, enseñanza.

Educational innovation, learning for well-being, learning community, research project, learning, teaching. 


\section{Introduction}

The demands of an educational society in rapid transformation point out the need for developing curricular and pedagogical dynamics that guarantee the acquisition of new learning and new skills in the school context. The gap between the needs of developed societies and the processes and results that the school is able to offer, becomes the starting point for this research. Responses will require an integrated vision and action on behalf of the school and the territory based on the pillars of democracy and the values of human solidarity, respect for the student's person and his or her potential.

The 21 st century is being characterized by profound changes and, in a context of uncertainty, schools need to develop and adapt to change. The ability to develop educational changes and innovate depends, to a large extent, on the teacher's commitment (Carbonell, 2001; Cardoso, 2014; Fullan \& Hargreaves, 1996; 2000; Rio, 2013; Thurler, 1994). Fullan \& Hargreaves (1996) are peremptory "an educational change that does not involve teachers and does not have their support usually ends up as a change for the worse or for nothing" (p. 30). Leite \& Fernandes (2010) state that for the implementation of educational changes the existence of "physical, human and material conditions is necessary for this desire to materialize and, more than that, it presupposes, on the part of all teachers and the school itself, willingness to share and participate in this joint search for paths of innovation" (p. 200). In the opinion of Pinto \& Picado (2011), when the school is "unprepared, both in its functional framework and in its social role of formal education can contribute to the development individuals who are at risk of their academic, personal and social well-being" (p. 16).

Currently, there is a movement, all over the world, that wants to attribute to the school the mission of developing skills for life, "accepting that the fact that an important part of these skills is based on sciences that are poorly represented in current education programs" (Perrenoud, 2013, p. 154). The interest in promoting social and emotional skills in children and young people grew out of the awareness that they are essential for achieving success, not only at school but also in life in general. Over the past two decades, research on the implementation of socio-emotional learning programs has increased, and the results show a positive relationship between the implementation of these programs and positive social behaviours, as well as the improvement of school outcomes (Blake et al., 2015; CASEL, 2003, 2012, 2013, 2016; Durlak et. al, 2011; Weissberg et al., 2015; Zins et al., 2004). Currently, rapid technological advances, innovations in robotics and artificial intelligence lead to great impacts on people's lives. These advances will bring many benefits to society but may increase inequalities. As Miguéns (2017) states, currently the "need to promote digital literacy and the use of technologies in education for all is therefore of the greatest relevance" (p. 7).

Schleicher (2018) states that the educational community's greatest dilemma is that cognitive skills are those which, in turn, "that are also easiest to digitize, automate and outsource" (p. 231). The author states: schooling today needs to be much more about ways of thinking (involving creativity, critical thinking, problem solving and judgement), ways of working (including communication and collaboration), tools for working (including the capacity to recognize and exploit the potential of new technologies) and about the capacity to live in a multi-faceted world as active and responsible citizens (p. 31).

In Portugal, the report Student Profile on Leaving Compulsory Schooling was drawn up to serve as a political guideline for educational organization and to contribute "to the convergence and articulation of decisions inherent to the various dimensions of curriculum" (Ministério da Educação, 2017, p. 8). This report defended a humanist approach that assumes that the biggest challenge facing schools is to prepare our children and young people for an uncertain future. Sousa-Pereira and Leite (2019) posit that this report will lead to changes in pedagogical practices that will "promote critical thinking, autonomy, solidarity and attention to others, the ability to make decisions, and to live in a pluralistic and ever-changing society" (p. 120).

Mainly, the PMA-CEAG XXI project is rooted in the idea of holistic child development, as opposed to conventional approaches and embraces the principle of "school community as a whole" placing the child at the centre of the learning process and involving and empowering families and other community partners in the life of schools. In this challenge of "transporting the school buildings and traditional learning environments into the 21 st century (...) the pressure for change is particularly directed towards the role of teachers, leadership, educational support services, technology and spatial solutions and learning environments." (Kickbusch, 2012, pp. 87-88). Demanding lines of work and pedagogical action based on "research learning methods, based on projects or events, learning from creative problem solving and community learning processes" (Kickbusch, 2012, p. 88). In which the use of educational software and the integration of mobile phones and other portable technological platforms are part of a concept of learning 
for well-being, taking advantage of the daily lives of digital students outside of school and giving value and usefulness to technological devices in learning.

This article presents the PMA CEAG XXI project and an analysis of the effectiveness and efficiency of the PMA-CEAG XXI project is carried out in order to assess its impact.

\section{Promoting Change in Learning: Gulbenkian XXI School Learning Communities}

In the 2014/2015 school year a project called «Promoting Change in Learning - GulbenkianXXI School Learning Communities» (PMA-CEAG XXI) has been implemented. The PMA-CEAGXXI project was financed by the Calouste Gulbenkian Foundation, later associated Samsung Portugal with the installation of the Samsung Smart-School technological solution in participating schools. The PMA-CEAG XXI project fits into the new generations of educational policies, based on bottom-up action logics, recognizing the ability of schools and school communities to organize school grammar and create specific educational interventions, temporally and territorially diversified and contextualized to overcome their weaknesses and constraints (Verdasca, Ramos, \& Candeias, 2013). The project was implemented in three schools from Alentejo region, in the third and fourth grade (primary school), and in the fifth and sixth grades (middle school), 151 students were involved, divided into seven classes; 7 full 1st cycle teachers and 5 support teachers; and 22 2nd cycle teachers from different subject areas. Approximately $20 \%$ of students, despite attending the 3rd year of schooling, had an age difference, this fact indicates that they had already had retentions at least once. Sociographic data from the cohort of students participating in the PMA-CEAGXXI project indicate sociocultural and economic contexts of some vulnerability, taking into account the predictive power of those variables in school performance and, above all, in the quality of that performance.

The selection of schools took into account indicators from external evaluation reports, the relationship of proximity and collaboration existing with the municipality and other social actors with an educational impact on the community, the motivations of school leaders and teachers, the conditions and quality of infrastructure and school equipment (Verdasca, Ramos, \& Candeias, 2013).

The Gulbenkian XXI School Learning Communities sought to inscribe an educational vision based on an educational perspective that finds in the principles of action of "Learning for Well-Being". The "Learning for Well-Being" paradigm was one of the first and main references of this project, this new approach is inspired by the resolutions adopted by the main international bodies, namely:

1. World Health Organization (WHO) - defines health as "a state of complete physical, mental and social well-being, not merely the absence of disease or enmity" (Kickbush, 2012, p.29);

2. United Nations Convention of the Rights of the Child (UNCRC) - emphasizes the "right of children to reach their full potential and participate in decisions that affect their lives" (Kickbush, 2012, p.29);

3. United Nations International Children's Emergency Fund (UNICEF) - stresses the responsibility "to advocate for the protection of children's rights and to help meet their basic needs and expand their opportunities to reach their full potential” (Kickbush, 2012, p.29);

4. United Nations Educational, Scientific and Cultural Organization (UNESCO) - "the four pillars of learning, defined by the International Commission on Education for the 21st century, emphasize the fact that learning is a process" (Kickbush, 2012, p.11);

5. Council of Europe - described well-being as a universal human right, using the vision "Well-Being for All" perspective "to encompass individual wellbeing as well as societal and global well-being, extending to future generations" (Kickbush, 2012, p. 29).

In 2012, the book "Learning for Well-being: a policy priority for children and youth in Europe" was launched, written by IIona Kickbusch and considered a glossary of "Learning for Well-Being" policies. The main objective of the book is "to provide a conceptual understanding of the approach and a vision of the possibilities for those in Europe who are responsible for creating and influencing policy" (Kickbush, 2012, p. 8). The vision of "Learning for Well-Being" is defined by Kickbush (2012) as:

A world in which people learn how to fully engage and express who they are, living in the present moment while developing, challenging and creating themselves for the future in harmonious engagement with one's own self, family and friends, the community and the world at large. (p. 3)

The integrated structure of the "Learning for Well-Being" vision can be seen in figure 1. 


\section{Figure 1}

Integrated structure of "Learning for Well-Being"

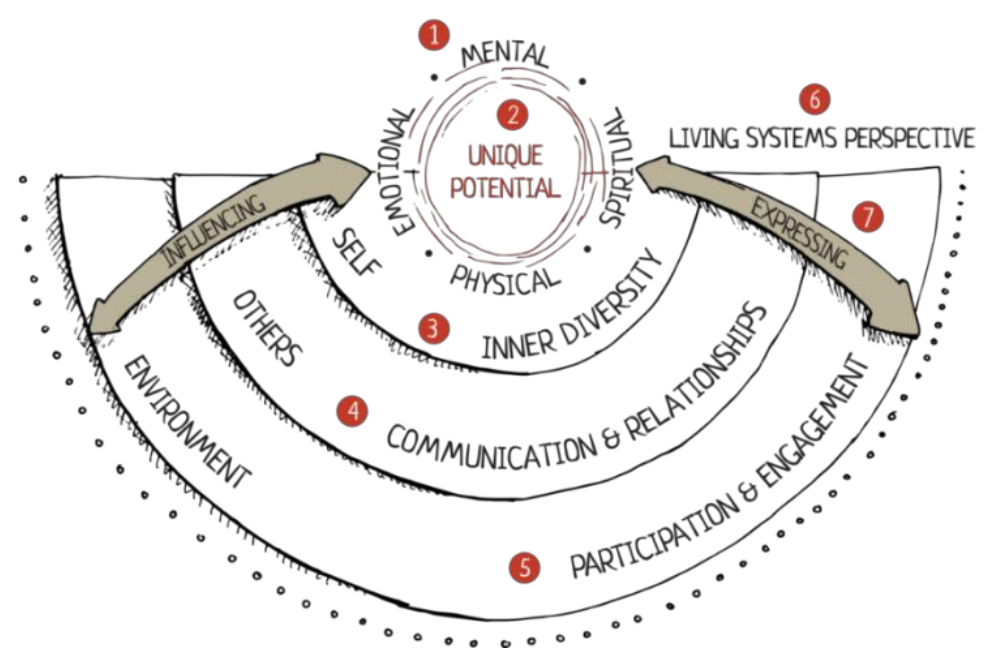

The integrated structure of "Learning for Well-Being" expresses well-being as the realization of our own potential (2), through physical, emotional, mental, and spiritual development (1) in relation to ourselves, others, and the environment. To note our unique potential, according to this approach, it is necessary to understand our inner diversity, our way of being in the world and the way we learn and develop (3). This approach defends the need to cultivate the ways in which we communicate and express ourselves, with others and with the environment in which we find ourselves (4). The "Learning for Well-Being" approach encourages us to take individual responsibility, to build practices, to make choices and to act (5). From this perspective, we need to recognize that our lives are dynamically interdependent with the systems we live in $(6 / 7)$ (Kickbush, 2012). This approach was designed according to the vision of how we would like the world to be: inclusive and solidary societies, where everyone realizes their unique potential throughout life. In this approach, it is believed that changes in societies are only possible through representatives and groups involved in holistic and systemic processes for themselves and for others.

The author highlights the need to change the way we think about learning, it should not be confined to the boundaries of school education. From the author's perspective, learning for well-being means a world in which people learn to be fully involved and express who they are, living in the present moment as they develop, in a harmonious commitment to themselves, family and friends, the community, and the world at large. Placing the child at the centre of the learning process imposes the principle of "recognis(ing) that the influence of continuous and rapid change upon today's learners and the consequent complexity of their lives require educators to inquire into new ways of working that support the well-being and learning connection" (Kickbusch, 2012, p. 79). This paradigm suggests that teachers and educators find new ways of working that support the interconnection between education and well-being based on interaction and interdependence supported by four aspects: learning environment; curriculum and pedagogy; partnerships; policies and procedures.

In this approach to the development and improvement, the practices of educators and teachers state: "what is learned through the curriculum will be practised in the learning environment, supported by partnerships with family and other agencies, and made explicit in the policies and practices" (Kickbusch, 2012, p. 79). Learning is essential to well-being and well-being is essential to learning, and there is a strong interconnection between them. A change of mindset and the way we think about children and young people, learning, health, education and society is needed. According to Kickbush (2012), policies and programs that aim to promote "Learning for Well-Being" must include five principles of action: take the child's perspective; encourage expression of each child's unique potential; focus on strengths and inner differences; emphasize the nature and quality of relationships; and be holistic. In regard to education, "Learning for Well-Being," despite focusing on learning in a broad sense, does not detract from the central place that the school occupies in this approach. According to this paradigm, schools need to become organizations of the

\footnotetext{
1 https://www.learningforwellbeing.org/our-approach/knowledge/
} 
21 st century "which enable Learning for Well-being by which we mean that they respect the individual development of each child." (Kickbush, 2012, p.80).

The PMA-CEAG XXI project closely followed the learning dimensions developed in this model and that Kickbush systematizes in five structuring axes:

1. the acquisition of skills takes place in an open space (inside and outside the classroom) enabling students to face the challenges of society's knowledge and information;

2. learning requires a framework of new assignments and places, the responsibility for the child's education and learning on parents, schools, teachers and communities;

3. inquiry learning with reference to problem- and project-based learning;

4. approach to learning from the environment and surrounding worlds and from the curriculum;

5. using modern technologies, exploiting state-of-the-art digital information and communication networks and platforms and ubiquitous learning environments.

Although the "Learning for Well-Being" paradigm is one of the first and main references, we cannot fail to mention other contributions as well, namely, resolutions of various international organizations (WHO, UNESCO, UNICEF), program "School of the Future," "ESSA Academy," "Responsible Education Program," and "European Schoolnet."

The "School of the Future" program, developed at the Ritaharjun Yhtenaisperuskoulu school, Oulou, Finland, whose efforts and directions are mainly centred on the learning capacity of students and the functional entities that support them, in the pressure for change directed mainly to the role of the teacher, leadership, technology, spatial solutions and learning environments, gaining a strong nuclearity the "inquiry learning methods, based on projects or events, learning from creative problem solving and community learning processes" (Kickbush, 2012, p. 88).

ESSA Academy will have been the first school in the UK to switch to a technology learning environment in 1 to 1 mode, with the distribution of an iPod Touch to each student. Associates to the technological component, the development of resilience, soft skills, in building the character of its students and teachers, considering these aspects as important as academic (Galloway et al., 2015).

In this same line of soft skills development, the "Responsible Education Program" of Botín Foundation, Spain, with the main objective of promoting physical, emotional, social growth, and creative students and teachers, increasing communication and improving school dynamics from working with teachers, students, and family would also constitute a source of inspiration. Especially, in the design of the socio-emotional and creative component of the PMA-CEAGXXI project. From the evaluations carried out on the implementation of the program, the promotion of students' emotional development, the prevention of violent behaviour and social isolation.

As far as technological environments as an educational resource, European Schoolnet created the Future Classroom Lab, a room with a fully equipped and reconfigurable teaching and learning environment that challenges participants to rethink the role of pedagogy, technology, and the design of classrooms, as well as iTEC (Innovative Technologies for an Engaging Classroom). This European project with the objective of promoting the use of digital technologies as a means of innovating pedagogical practices, was also an inspiring model that, in some way, would stimulate the strong investment that would come to be made in technological environments as a resource to support learning, with a protocol signed between the Calouste Gulbenkian Foundation and Samsung. The Samsung Smart-School solution supported the technological environment of the PMA-CEAGXXI project, in 1 to 1 mode. The management would be entirely up to the school/teacher and, due to its characteristics, allowing teachers to follow on their own tablet or on the Samsung Smart Touch TV monitor in the classroom what each student would find themselves doing, being able to project the work of that student, of a group of students, of all students, with full control of situations in the context of the classroom and reinforcement of the teacher's pedagogical leadership (Verdasca, 2016).

\subsection{Conception and strategy of the Gulbenkian XXI School Learning Communities}

The previous principles led to the need to establish local and regional partnerships, or even with a broader geographic scope, between the project schools and reference institutions with recognized competences in the context of formal and informal educational and curricular practices. It was in this context that several collaboration protocols were signed (Centre for Live Science of Estremoz; Eugénio de Almeida Foundation; ICT Competence Centre at the University of Évora; Municipalities, publishers -Porto Editora- and the Ministry of Education). The interrelationship between well-being and learning requires strategies and logics of action that generate opportunities and the local construction of educational dynamics in convergence and complementarity, with emphasis on the clear option for an open and enriched 
curriculum approach, introduction of technological environments, development of socio-emotional and creative skills, with the main objective of providing students with a set of skills that combine knowledge, skills, and attitudes. This strategy provided new challenges, promoted new forms of institutional cooperation, it unleashed countless and diversified learning opportunities with the mobilization of other sources of knowledge, other actors, other languages, other educational resources, other locus and learning contexts.

A model structured in three large dimensions was outlined, aggregating the five structuring axes of the paradigm "Learning for Well-Being" and which was given an adaptive configuration to the school context. Both learning and well-being, in their cognitive and affective dimensions, influence and interact with each other, and they are themselves powerful enablers of creating learning environments that open up and expand opportunities for new ways of exploring and developing the curriculum, providing students to experience and enjoy moments and learning contexts that strongly enhance their psychomotor, emotional, mental, and spiritual development in relation to themselves, others, and the environment.

Figure 2

PMA-CEAGXXI reference model

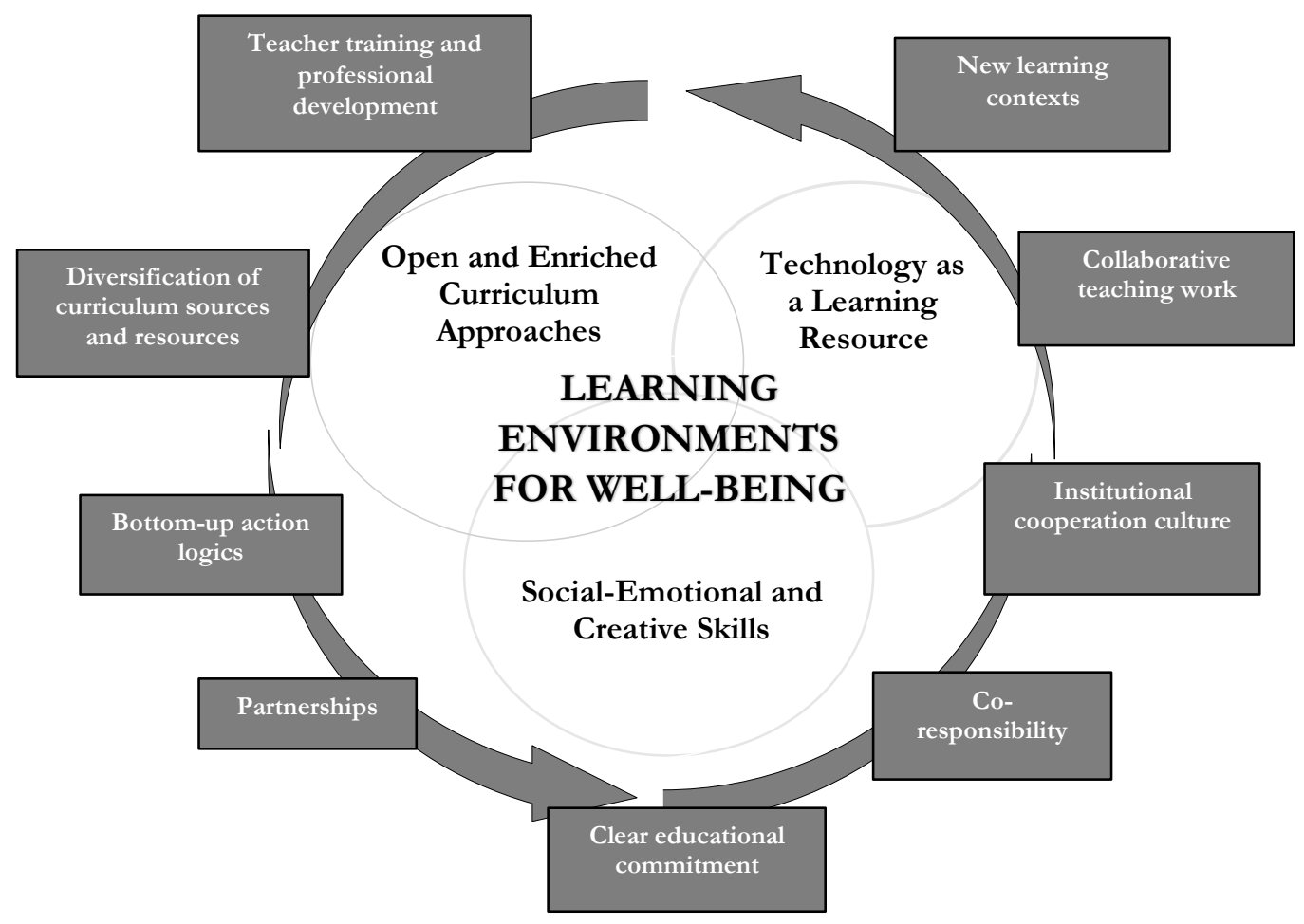

The PMA-CEAG XXI approach is anchored in strategic school actions that prioritize and bet on convergent and interdependent educational dynamics and which can be perceived, in the figure, as the pillars that operationalize "Learning for Well-Being", namely:

1. open and enriched curricular practices, inside and outside the conventional classroom, using a variety of curricular sources, with the participation of other actors in the community, even under the pedagogical leadership of the teachers, mobilizing other educational resources. In this model, it was not a matter of a new curriculum, but rather different methodological approaches to this curriculum;

2. integration of portable technological devices and use of educational software in a new conception of learning that seeks to take advantage of the students' daily lives inside and outside the school, giving it value and usefulness as a tool to support learning. The fact that the Samsung Smart-School solution implemented in each of the classrooms allows individual monitoring, the regulation of students by teachers in pedagogical dynamics, reinforces teachers' pedagogical leadership, and facilitates the acceptance and naturalization of technology as a learning resource;

3. experiential learning from the active participation of students in cultural and artistic projects and where, through socio-emotional, creative and kinesthetic-body processes, they generate opportunities for students to develop their abilities to understand and value emotional knowledge, express, and self-regulate your emoticons. 
To support the above components is the strategic dimension of prior and continuing teacher training and a whole logic of action for professional and personal teacher development. According to Carbonell (2001), training should take place on two complementary planes: the individual "with the continuous acquisition of solid and updated knowledge in the different areas of knowledge" (p. 130); and the collective plan, "with the exchange of ideas and experiences and cooperative work that promotes an innovative culture in schools and a future more cultured, critical and solidary citizenship" (Carbonell, 2001, p.130). The key to the success of the training is the reflection that is carried out by the teachers. The teacher has a very important role in this century, it will never be able to replace the role that the teacher occupies in the teaching and learning process, because the desired relationship between teacher and student will always be at the centre of the pedagogical mission (Day, 2001; Mesquita, 2013; Nóvoa, 2007).

During the four school years, participating teachers were provided with specific training programs which, as the project coordinator states, "the key to the process would lie in the ability to respond quickly to the problems and needs felt by the teachers and to make them feel autonomous and able to explore new approaches and new resources and without loss of pedagogical leadership." (Verdasca, 2016, p.33). As part of the socio-emotional and creative component, a training plan called "Mediators for Well-Being" was developed. The "Mediators for Well-being" continuous training plan followed the development of the project and was based on the teacher's reflective development model (reflection model-in-action by Schön, 2000), the training was carried out in a comprehensive context that included well-being, emotional intelligence, sustainability, community content, learning, curricular transversality, project work, and digital skills.

The intervention carried out in the project aimed to naturalize educational dynamics that promote a new set of skills and learning from the collective and collaborative curriculum construction.

\section{Method}

Cohort studies, as far as the analytical model of the evolutionary schooling processes of students and the respective demographic-schooling events associated with them, incorporate and highlight analytical elements of aspects directly related to the internal dimension of the "school production structure". On the other hand, the establishment of "results/time" relationships, apart from being methodologically of great applicative agility, allows the calculation of several indicators of educational effectiveness and efficiency and proximity to the concept of school productivity as it provides information on the school performance of generations of students from schools and territories per unit of time, in school years (Dacal, 1996; Verdasca, 2002).

In this sense, the methodology adopted is about comparing the school performance, measured through four different indicators, of the PMA-CEAGXXI cohort of students in their four-year school pathway with the overall cohorts of students in Alentejo and in the country (mainland) for the same school years (trajectories from the 3rd to the 6th year of schooling) and for the same time period (from the school year $2014 / 15$ to the school year 2017/18).

The indicators selected were the following: retention rate, indicating the number of students every 100 who are retained in each curricular year; school performance (internal), a coefficient stating the relationship between the product of the number of curricular years of education cycles by the total number of cohort students who successfully completed the four years of education in four school years and the respective volume of student-years generated; the cohort's completion rate, corresponding to a direct path of success and reflecting.

\section{Results}

The results of the comparisons are projected in the following figures, each one referring to an indicator. The figure 3 show regularities in the retention rates of the three groups: Public Schools - Mainland Portugal; Public Schools - Alentejo Region; Public Schools - PMA CEAGXXI. 


\section{Figure 3}

Comparative analysis of retention by cohort of students

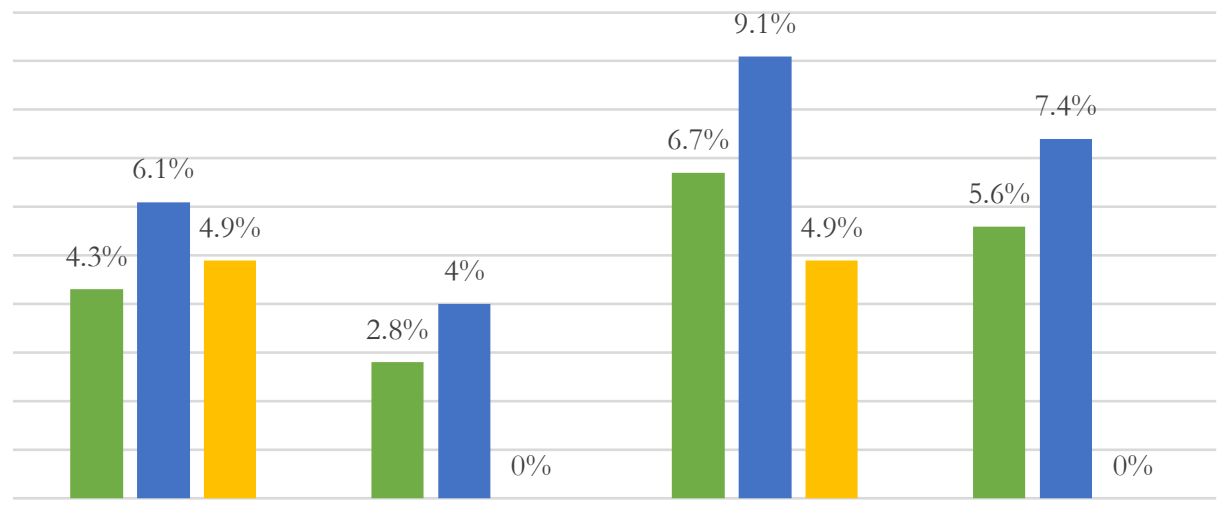

— Public Schools - Mainland Portugal — Public Schools - Alentejo Region

nublic Schools - PMA CEAG XX

The PMA-CEAG XXI group always achieving significantly lower retention rates than the cohorts of students from Alentejo and the country, especially from the 4th year of schooling onwards, with even $0 \%$ at the end of the cycle, that is, in the 4th and 6th years of schooling.

Figures 4 and 5 show hierarchical structures of the school performance calculations, expressed in terms of the simple retention index.

\section{Figure 4}

Hierarchical structure of school performance by cohort in the 3rd and 5 th grades of schooling using the CRT method

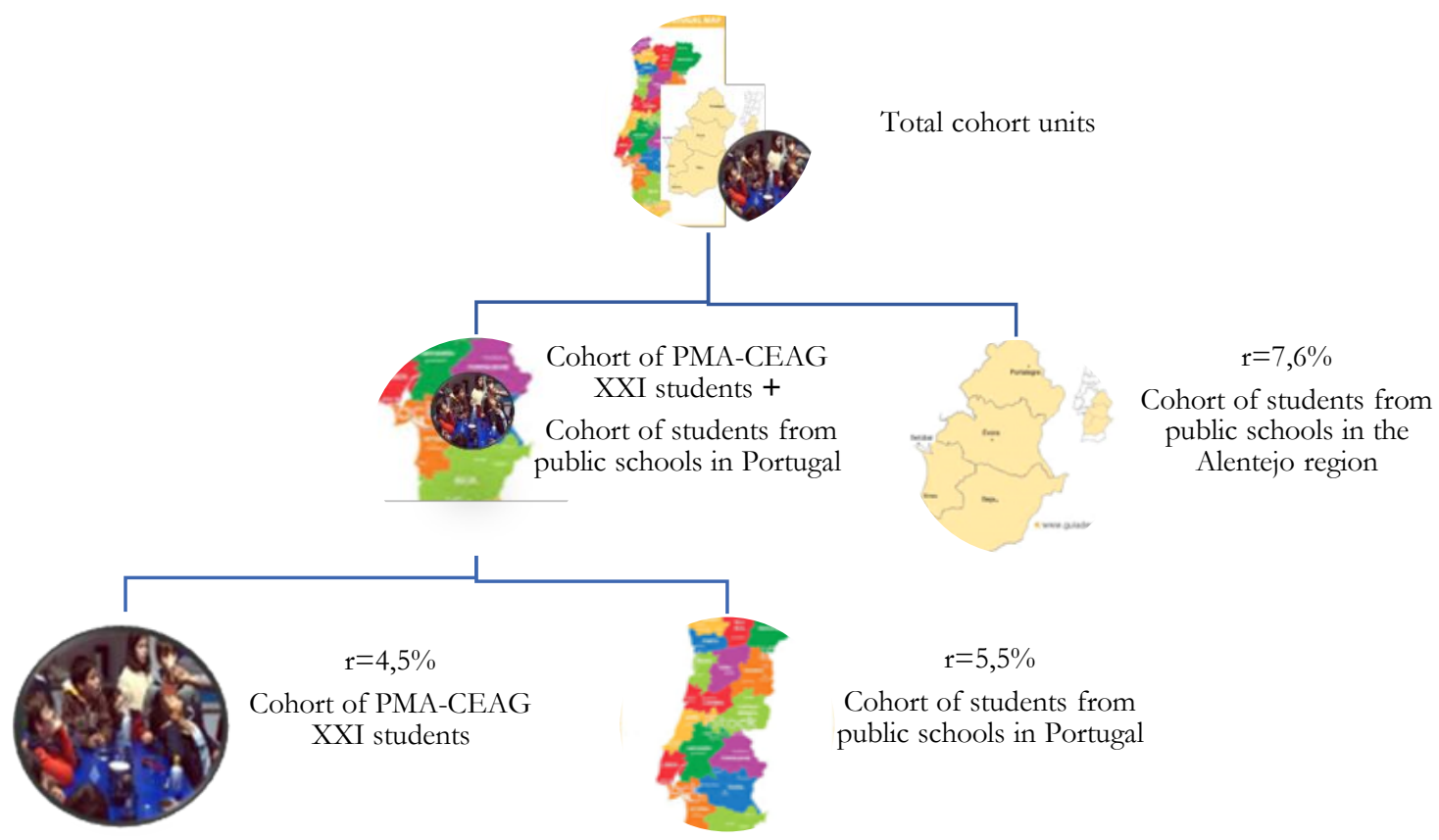

\section{Figure 5}

Hierarchical structure of school performance by cohort in the 4th and 6th grades of schooling using the CRT method 


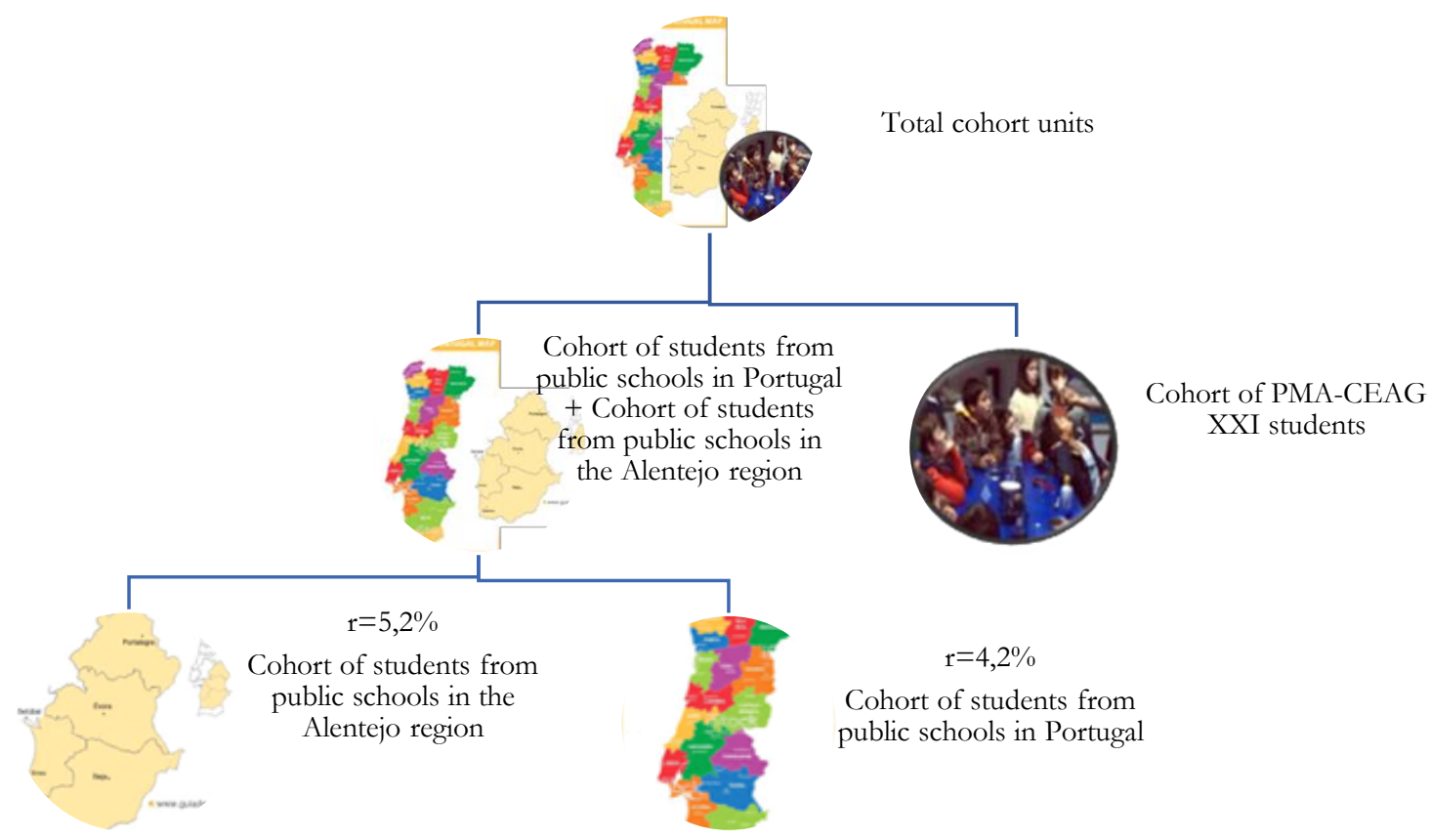

Differences in performance after applying the CRT method (Pestana \& Gageiro, 2009), suggest the existence of segmentations at two levels of depth, depending on the curricular year between the three cohort groups. In the cases of the 3rd and 5th years of schooling, what tends to prevail is a first level of segmentation that separates the cohort group "Alentejo" from the cohort groups "PMA-CEAGXXI" and "total Continente" and only at a second level of depth do these last two cohort groups segment. In the case of the final curricular years of cycle, 4th and 6th years, at the first level, the solution segments the "PMACEAGXXI" student cohort from the others and separates the "total Continente" and "total Alentejo" student cohorts, it occurs only at the second level of depth.

The next two composite indexes measure result/time relationships. They were calculated using the simplified trajectory projection method (Verdasca, 2002; 2019). In the cohort completion rate, the group of PMA-CEAGXXI students stands out from the rest, achieving that more than $90 \%$ of the students who integrated the project in the 3rd year of schooling in 2014/15 completed the 6th year of schooling four academic years later, in 2017/18. The differences are significant, both for the national group, which registers only about $82 \%$ in the indicator, and for the total number of students in Alentejo, where this figure shows that practically a quarter of students failed to complete the four curricular years in four academic years. School performance is an indicator of educational efficiency that translates "the relationship between the theoretical number of student years that the school population would take to complete the education cycle if there were no dropouts or repetitions of years and the number of student years that actually needs" (UNESCO, 1994, pp. 112-113). Also in this indicator, the cohort group of PMA-CEAGXXI students reveals a residual relative school waste $(2.3 \%)$, in contrast to the much lower levels of income recorded by the other groups, whose results show income values that are around $5 \%$ and $6 \%$ of the ideal theoretical maximum. 


\section{Figure 6}

Internal school performance and cohort completion rate

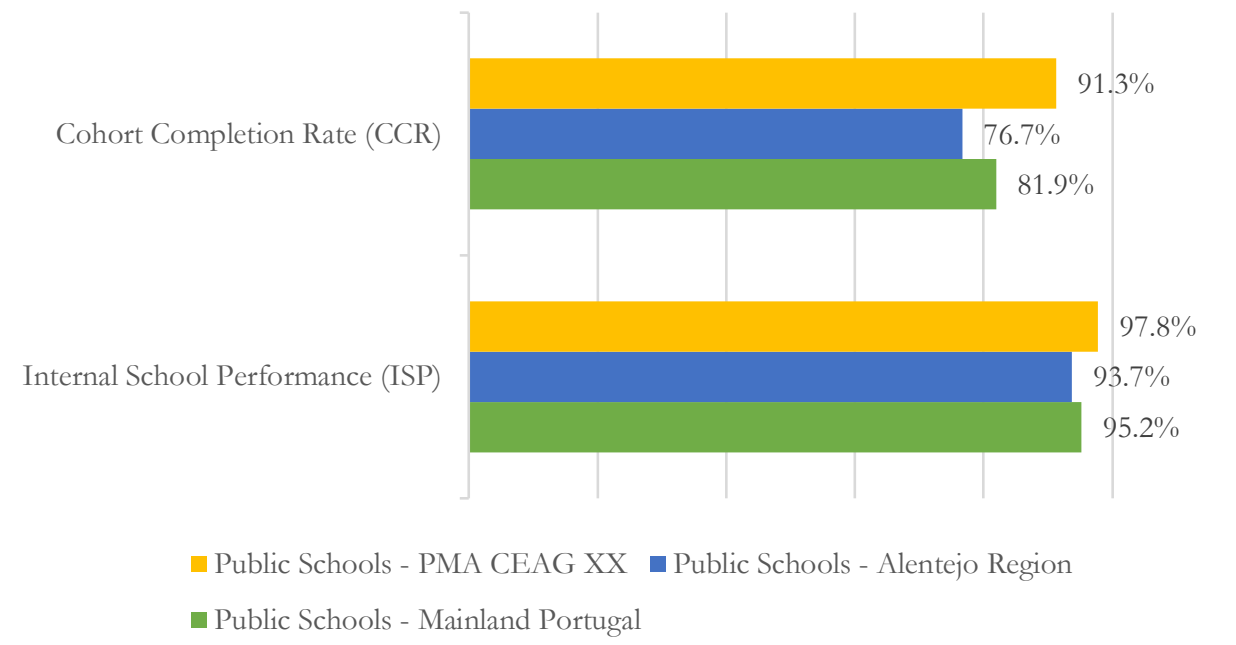

The average completion time indicator shows the number of academic years required to complete each curricular year or, when analysed as a whole, the average completion time of the teaching cycle. The differences between the three student groups are well highlighted in the data in the figure 7 and again with significant advantage for the PMA-CEAGXXI student group.

\section{Figure 7}

Average completion time

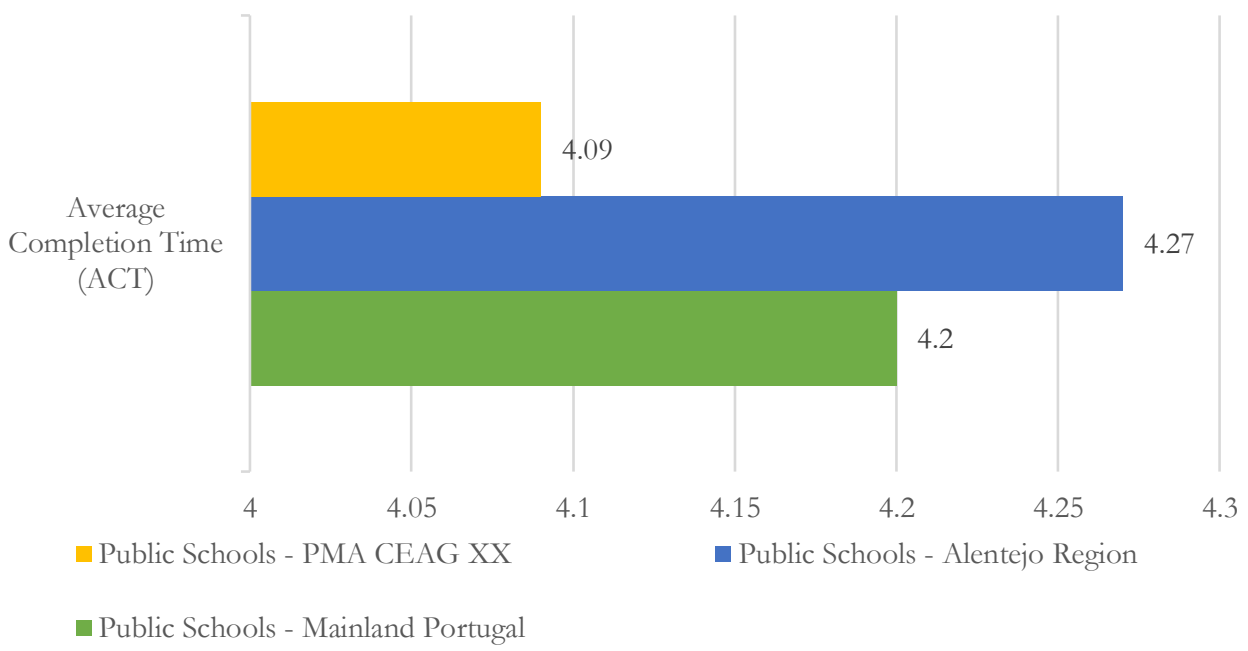

The cost/increase coefficient corresponds to the inverse of school performance. In theory, it is located in a corridor of values that has a lower threshold of unity, translating the ideal (optimal) situation into a cost coefficient of one unit of student-years for each graduated student, and being, therefore, the addition of diploma costs is equal to the difference between the coefficient obtained and the unit (Verdasca, 2002; 2019). 


\section{Figure 8}

Coefficient of increase and costs

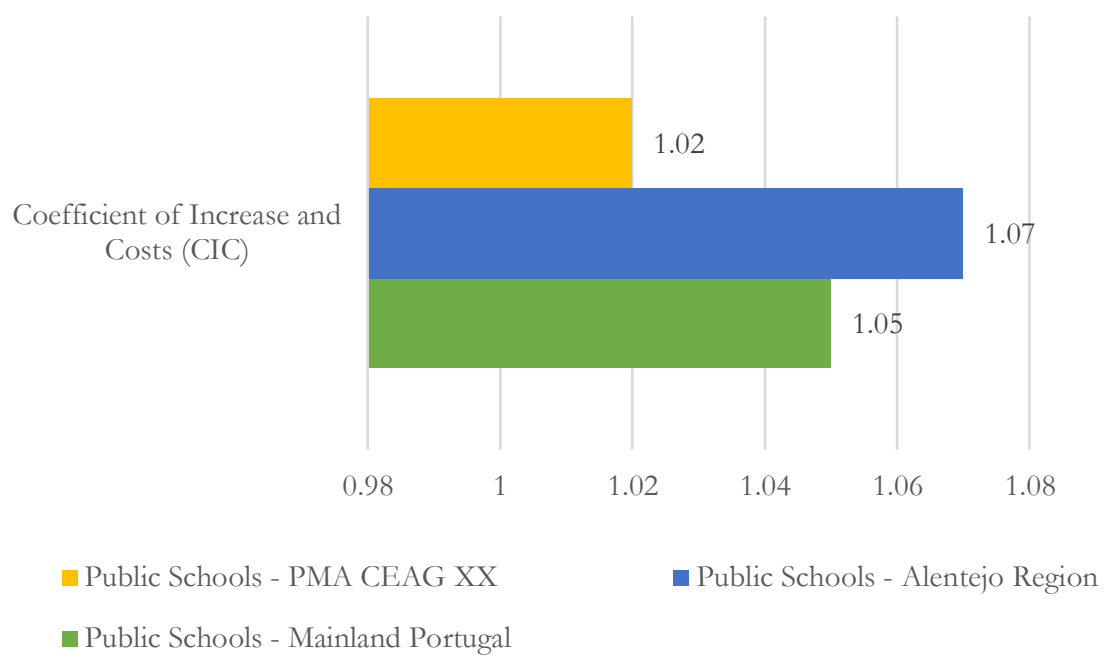

The calculations performed to determine the performance of the three cohort groups of students are shown in figure 9.

\section{Figure 9}

Simulated comparison of additional costs generated

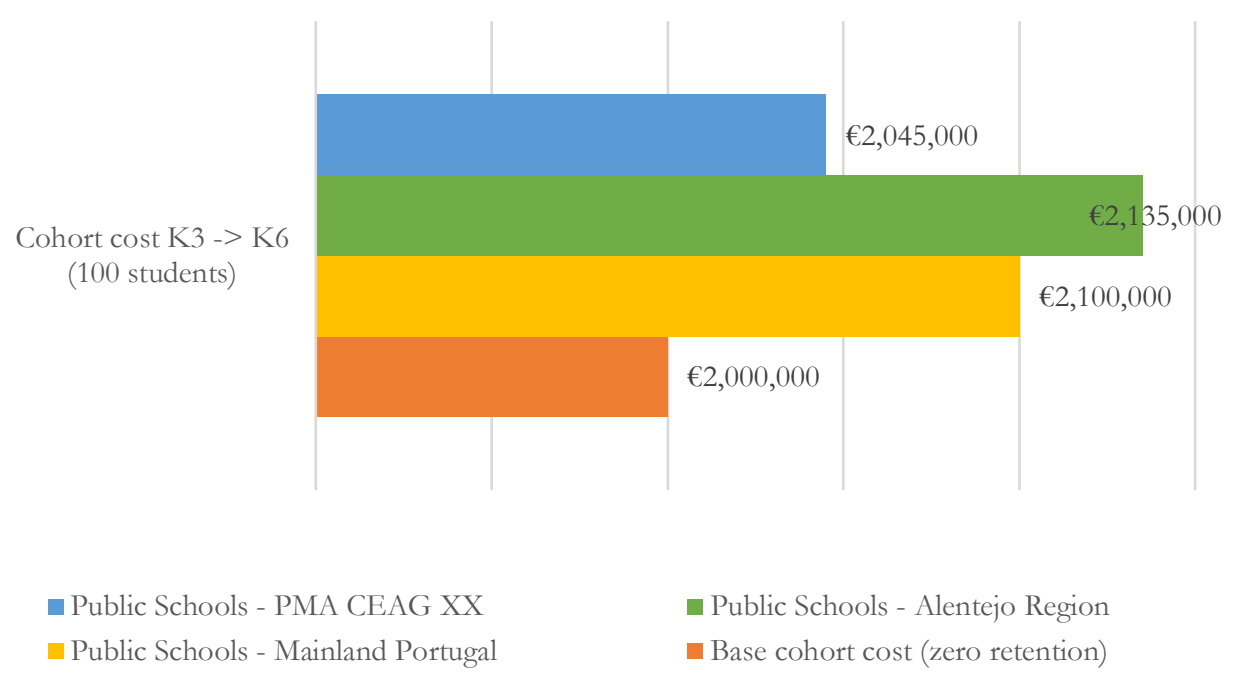

The simulation of costs per 100 students associated with the respective coefficients resulting from the school performance of the three cohort groups is shown in the figure. There is an increase of $2 \%$ for PMACEAGXXI students and more than doubles and triples for the country and Alentejo total, respectively. The differences are suggestive enough to be able to conclude on the existence of the socio-educational return effect generated in the scope of the PMA-CEAG XXI project.

By analysing the results, we can highlight that the psychopedagogical intervention focused on curriculum diversification, open curriculum, the work of teaching teams, learning based on multidisciplinary projects and the emphasis on problem solving, creativity, socio-emotional literacy and informal learning, supported by innovative methodologies and supported by new technologies they do not prevent students from continuing to learn the basic tools and curriculum content provided. We found that the students in the intervention group do not decrease their academic performance, but progressively consolidate their interpersonal problem-solving skills, their motivation and persistence towards learning, as well as developing their thinking and creative competence both verbally and in figurative terms. 


\section{Conclusions}

The interrelationship between learning and well-being was supported by a strategy that brought together open, transversal, and enriched curricular approaches, technological environments to support learning in daily school life, development of socio-emotional and creative skills, training in context and professional development of teachers. This strategy provided students with a vast and diverse set of opportunities for school experiences and learning within and outside the traditional space of the school and the classroom, with new challenges for students and teachers and induced the need to work collaboratively and in conjunction with other actors and community partners and to strengthen partnerships with institutions in the territory. As a result, new teaching and learning contexts were recreated, providing students with more autonomous ways of learning and the use of technological resources as a means of learning, the mobilization of other complementary sources of knowledge, other actors, other resources educational and learning spaces.

Over the four years of intervention with students, emblematic curricular projects emerged locally, with teachers taking on new methodologies and pedagogical dynamics inspired by the PMA-CEAGXXI challenges. These dynamics emerged in an almost natural way, with teachers and other educational actors from the Gulbenkian XXI School Learning Communities providing students with disciplinary and transdisciplinary situations of learning through experience, socio-emotional, creative and kinaesthetic-body processes, learning experiences relating theoretical and practical knowledge, deepening their scientific knowledge, curiosity and interest through observation and experimentation. These challenges led students to the creation of artistic installations and transdisciplinary school projects with demonstration of technological skills of some sophistication in its production and presentation, participation in events and exchanges at local, national, and international level with the opportunity to exhibit projects developed in the school context and outside it, and to interact with other national and foreign students.

When the entire school context invests and cares about this type of programs, students experience the school environment as safe, being more motivated to learn and increase their commitment to the school. It is not just necessary to be emotionally intelligent, it is crucial to be motivated to use that intelligence (Silva e Franco, 2014). On the other hand, there is the effect of school transition in which the school results of the PMA-CEAGXXI group of students remained positive over the four years, which suggests, once again, and as has been reported in previous studies the need to safeguard the model of transition from the 1st to the 2nd cycle, given its coincidence with a moment of critical psychological development and transition from childhood to adolescence (Coelho et. al, 2016; Silva e Franco, 2014).

In terms of general indicators of educational effectiveness and efficiency such as, for example, cohort completion rates 3rd -> 6th grade, internal school performance and average time to cohort completion, PMA-CEAGXXI students recorded in the three score indicators significantly higher than the average for public schools in Alentejo and mainland Portugal.

Nevertheless, from the results of the PMA-CEAGXXI research-action project, there are also suggestions for intervention and recommendations at different levels of action:

- inclusion of social-emotional content in the curricular and extracurricular scope, in a formal and informal way;

- training and supervision of teachers to act as mediators in the development of cognitive and creative skills through multiple approaches (formal and informal);

- training and involvement of parents/families in the development of socio-emotional, cognitive and creative skills in close and continuous articulation with teachers;

- expansion of the open and enriched curriculum approach model to the various areas of the curriculum, incorporating new partners in the territory and expanding networks of cooperation and collaborative work between teachers and actors with an educational impact on the community;

- naturalization of the use of technological means as a learning resource, preferably in a one-to-one mode and supported by self-regulated systems, in an integrated action logic whose curricular references and implementation models are previously supported in training processes in a school context inspired by the content paradigm curriculum-technology-pedagogy.

Finally, in terms of future research, we consider it relevant to develop broader studies and in diversified territorial contexts, which extend the analysis to the impact of programs inspired by the framework of values and principle of the framework Promoting Changes in Learning and in the educational perspective Learning for the Well-Being at the expectations of children and young people about their learning process, well-being and development, as well as those of their teachers and families, in an ecological and systemic perspective.

\section{Limitations}


The main limitation of the present study is the fact that, for the results to be generalizable, due to the specificity of the PMA-CEAG XXI project, it is necessary to replicate the investigation in other schools and in other contexts.

\section{Funding}

This work is financed by national funds from FCT - Foundation for Science and Technology, I.P., within the scope of the project UIDP/04312/2020.

\section{References}

Blake, P. R., Piovesan, M., Montinari, N., Warneken, F., \& Gino, F. (2015). Prosocial norms in the classroom: The role of self-regulation in following norms of giving. Journal of Economic Bebavior \& Organization, 115, 18-29. https://doi.org/10.1016/j.jebo.2014.10.004

Carbonell, J. (2001). A aventura de inovar: a mudança na escola. Porto Editora.

Cardoso, A. (2014). Inovar com a investigação-ação: desafios para a formação de professores. Imprensa da Universidade de Coimbra. http://dx.doi.org/10.14195/978-989-26-0666-8

Coelho, V., Sousa, V., \& Marchante, M. (2016). Atitude Positiva: Um resumo de 12 anos de resultados de aplicação de programas de aprendizagem socioemocional. In A. Marques-Pinto, \& R. Raimundo (Eds.), Avaliação e promoção de competências socioemocionais em Portugal (pp. 373-398). Coisas de Ler.

Collaborative for Academic Social and Emotional Learning (CASEL) (2003). Safe and Soud: An Educational Leader's Guide to Evidence-Based Social and Emotional Learning (SEL) Programs. Collaborative for Academic Social and Emotional Learning.

Collaborative for Academic Social and Emotional Learning (CASEL) (2013). Implementing Systemic District and School Social and Emotional Learning. Collaborative for Academic Social and Emotional Learning.

Collaborative for Academic Social Emotional Learning (CASEL) (2012). Effective Social and Emotional Learning Programs: Preschool and Elementary School Edition. Collaborative for Academic Social and Emotional Learning. http://casel.org/wp-content/uploads/2016/ 01/2013-casel-guide-1.pdf

Collaborative for Academic Social Emotional Learning (CASEL) (2016). SEL Impact. Collaborative for Academic Social and Emotional Learning. http://www.casel.org/impact/

Dacal, G. (1996). Curso de Organización Escolar y General. Editorial Escuela Española S.A.

Day, C. (2001). Desenvolvimento profissional de professores: os desafios da aprendizagem permanente. Porto Editora.

Durlak, J. A., Weissberg, R. P., Dymnicki, A. B., Taylor, R. D. \& Schellinger, K. B. (2011). The impact of enhancing students' social and emotional learning: A meta-analysis of school-based universal interventions. Child Development, 82(1), 405-432. https://doi.org/10.1111/j.1467-8624.2010.01564.x

Fullan, M. \& Hargreaves, A. (1996). What's Worth Fighting For In Your School. Teachers College Press.

Galloway, J., John, M., \& McTaggart, M. (2015). Learning With Mobile And Handheld Technologies: Inside And Outside The Classroom. Taylor \& Francis LTD.

Kickbusch, I. (2012). Aprender para o Bem-Estar: uma prioridade politica para criancas e jovens na Europa - um processo de mudança. Fundação Calouste Gulbenkian.

Kickbush, I. (2012). Learning for Well-Being: A Policy Priority for Children and Youth in Europe. A Process for Change. Calouste Gulbenkian Foundation

Leite, C. \& Fernandes, P. (2010). Desafios aos professores na construção de mudanças educacionais e curriculares: que posibilidades e que constrangimentos? Educação, 33(3), 198-204. https://bit.ly/3sMkykx

Mesquita, E. (2013). Competências do Professor: representações sobre a formação e a profissão. Edições Sílabo.

Miguéns, M. (2017). Nota Prévia. In Conselho Nacional de Educação, Aprendizagem, TIC e Redes Digitais (pp. 6-11). Conselho Nacional de Educação. https://bit.ly/3qzxDLv

Ministério da Educação (2017). Perfil Dos Alunos à Saída da Escolaridade Obrigatória. Ministério da Educação.

Nóvoa, A. (2007). Desafios ao trabalho do professor no mundo contemporâneo. SINPRO-PS.

Perrenoud, P. (2013). Desenvolver competências ou ensinar saberes? A escola que prepara para a vida. Penso.

Pestana, M., \& Gageiro, J. (2009). Análise categórica, árvores de decisão e análise de conteúdo em ciências sociais e da saúde com o SPSS. Lidel.

Pinto, A. \& Picado, L. (2011). Adaptação e bem estar nas escolas portuguesas: dos alunos aos professores. Coisas de Ler.

Rio, J. (2013). O Professor do Futuro. Editora Guerra \& Paz. 
Schleicher, A. (2018). World Class: How to build a 21st-century School System, Strong Performers and Successful Reformers in Education. OECD Publishing.

Schön, D. A. (2000). Educando o profissional reflexivo: um novo design para o ensino e a aprendiragem. Artes Médicas Sul.

Silva, E., \& Franco G. (2014). Relação entre a Inteligência Emocional e o rendimento escolar em crianças do $1^{\circ}$ ciclo do Ensino Básico da RAM. International Joumal of Developmental and Educational Psychology, 1 (2), 419-428.

Sousa-Pereira, F., \& Leite, C. (2019). Students profile leaving compulsory education policy and challenges for teacher training. Educação, Ciência e Cultura, 4, 113-122. https://doi.org/10.18316/recc.v24i1.5603

Thurler, M. (1994). Levar os professores a uma construção activa da mudança. Para uma concepção da gestão da inovação. In M. Thurler \& P. Perrenoud, A escola e a mudança (pp. 33-59). Escolar Editora.

UNESCO (1994). Declaración sobre necesidades educativas especiales: Acceso y calidad de Salamanca. UNESCO.

Verdasca, J. (2002). Desempenho Escolar, Dinâmicas de Evolução e Elementos Configuracionais Estruturantes. [tese de doutoramento, Universidade de Évora]. https://bit.ly/3FNUoBF

Verdasca, J. (2016). Inclusão, Inovação e Bem-Estar: a experiência das comunidades escolares de aprendizagem Gulbenkian XXI. In C. Palmeirão e J. Alves (coord.), Promoção do Sucesso Educativo: estratégias de inclusão, inovação e melhoria - conhecimento, formação e ação (pp. 9-39). FEP-UCP.

Verdasca, J. (2019). A Escola na Linguagem dos Indicadores. Edições Colibri.

Verdasca, J., Ramos, J., e Candeias, A. (2013). Comunidades Escolares de Aprendiragem Gulbenkian XXI. Proposta apresentada à Fundação Calouste Gulbenkian no âmbito do Programa Gulbenkian Qualificação das Novas Gerações - Promoção de Mudanças na Aprendizagem. CIEP-EU.

Weissberg, R., Durlak, J., Domitrovich, C., \& Gullotta, T. (2015). Social and emotional learning: past, present, and future. In J. Durlak, C. Domitrovich, R. Weissberg, and T. Gullotta (Eds.). Handbook of Social and Emotional Learning (pp. 3-19). The Guilford Press.

Zins, J., Bloodworth, M., Weissberg, R., \& Walberg, H. (2004). The scientific base linking social and emotional learning to school success. In J. E. Zins, R.P. Weissberg, M.C. Wang, and H. J. Walberg (Eds.), Building academic success on social and emotional learning: what does the research say? (pp. 3-22). Teachers College Press. 